\title{
Neo-Racism and the Criminalization of China
}

\author{
Jenny J. Lee \\ University of Arizona, USA
}

Earlier this year, the Federal Bureau of Investigation (FBI) elevated "hate-fueled violence" to a top national security priority, putting racist violence on the same threat level as terrorist groups such as ISIS (Allam, 2020). In other words, there are just as many serious challenges to safety inside the United States as outside its national borders. And much of this danger is racially motivated. Among the leading targets are immigrants or those who appear as immigrants. For example, the United States experienced a surge of random attacks against those of Asian descent earlier this year, as they were wrongfully blamed for spreading COVID-19 (Wang, 2020).

As for U.S. higher education, international students have been both threatened and viewed as threats. Especially since $9 / 11$, they have been under the presumption of being an endangerment to the safety of Americans. This remains evident today, not just in current federal procedures, such as the Student Exchange Visitor Information System (SEVIS) but also in current political rhetoric and selective immigration policies. One clear example is the Department of Homeland Security (DHS) rule months ago that international students would be deported if their universities go online (Castiello-Gutiérrez \& Li, 2020). In their appeal in the Harvard and MIT lawsuit (President and Fellows, 2020), DHS explicitly stated to the courts that international students would otherwise be a threat to "national safety."

In response, we witnessed a massive public outcry across educational, governmental, and commercial sectors in support of internationals and arguing for the wealth of benefits they bring. And, while DHS rescinded that rule soon after, there has remained numerous, more selective targeting toward a certain type of international: those from China. The general public has less opposed this anti-China neo-racist focus.

\section{NEO-RACISM}

What is neo-racism? This is a new racism that is not based on the color of one's skin alone but includes stereotypes about cultures in a globalizing world (Balibar, 1992; 
Lee \& Rice, 2007). It is also based on a hierarchy of cultural preferences, as not all internationals are unwelcomed. The commonly used term xenophobia does not capture ways that Chinese students are targeted over those coming from Canada, Australia, or Western Europe. What is also distinctive about neo-racism, unlike oldfashioned racism or even blanket xenophobia, is a national ordering, used to justify the filtering and differential treatment of immigrants. Ultimately, neo-racism is rooted in White supremacy (Stein \& de Andreotti, 2016; Suspitsyna \& Shalka, 2019).

Also, neo-racism is rationalized differently. To provide some brief context, the term was originally conceptualized by the sociologist Etienne Balibar (1992). He had observed France's long mistreatment against those of Arab and North African descent. The justification was that these groups posed direct threats to what it meant to be French. The rationale was to protect a so-called "French way of life" by maintaining cultural boundaries. These same unchecked assumptions are used to promote restrictive immigration and mistreatment in the United States today. Discrimination then appears defensible by those who marginalize such groups. Their rationale is based on cultural difference or national origin rather than by race alone. This disarms the fight against racism by appealing to assumed "natural" tendencies to preserve the culture of the dominant group, i.e., White Europeans.

Neo-racism can also be observed in academia. International students have reported experiences of verbal assaults, false accusations, sexual harassment, and even physical violence (Lee, 2017; Lee et al., 2017; Lee \& Rice, 2007). But these experiences are not uniformly experienced across all internationals. In the case of the United States, neo-racism is targeted toward those from Asia, Latin America, and Africa, in ways that are not experienced by those from the Western world.

Neo-racism can be evidenced across a range of higher education sectors. For instance, many U.S. universities benefit from the athletic prestige that international athletes offer. In one study, Thomas Opio and I (2011) demonstrated the neo-racist experiences of African student athletes who were tapped and recruited for their athletic prowess but felt unsupported when it came to their academic goals. In some cases, they were steered toward majors that would be of little relevance back home. They also experienced negative stereotyping from domestics, including African Americans, about their homelands.

Neo-racism underlies the scientific enterprise as well. In another study, Brendan Cantwell and I (2010) identified ways that Asian postdocs are systematically channeled to unsecure, short-term contracts while White nationals are groomed toward faculty positions. Faculty reported them as being good at "technical" work and managing labs but lacking the theoretical depth to become true scholars. We observed a similar pattern among international graduate students with some indicating they served as cheap labor, funded to work on their supervisors' projects that were unrelated to their professional ambitions (Cantwell et al., 2018). These graduate students reported feeling exploited yet helpless to challenge their faculty advisors. The broader patterns we observed exemplify ways that Asia maintains the United States' dominant role in science as temporary laborers but are excluded as fellow members of a shared society, with equal rights, protections, and entitlements. These are just some of the ways that neo-racism operates. 
It is also important to be clear that cultural discrimination is not a U.S.phenomenon only. Based on my research in South Korea and South Africa, there is a similar scapegoating against so-called foreigners based on negative stereotypes. In some cases, they can occur along similar racial lines, which I refer to as neonationalism. In the case of South Korea (Lee et al., 2017), neo-nationalism was against those from China; whereas in South Africa, students from Zimbabwe and Nigeria were particularly affected (Lee, 2017).

\section{CRIMINALIZATION OF CHINA}

Neo-racist stereotypes have also long been used to maintain illusions of national security in which certain groups pose a "danger." In the United States, neo-racism was keenly observed post-9/11 in the mistreatment of Middle Eastern people. More recently, we observed the widespread Muslims bans that are still in effect for particular countries, and now the criminalization of China. Lately, as demonstrated by the White House and federal agencies over and over again, there is the negative stereotyping of China, particularly as criminal. Such examples over the past 2 years are as follows:

- Sweeping political rhetoric of Chinese researchers and graduate students as spies

- Visa limits for Chinese graduate students in high-tech fields to 1-5 years

- Visa exclusions for those with ties to the Chinese Community Party and Chinese military

- $\quad$ FBI-University protocols to monitor Chinese scientists and scholars (Lee \& Haupt, 2020a, 2020b)

In response, there have been mounting calls from major organizations and university leaders that the federal government is engaging in racial profiling. Presidents of leading research universities (MIT, UC Berkeley, Stanford) and major associations have also openly denounced such discrimination based on one's nation of origin and affirmed their commitment to their institution's and academia's international community (e.g., MIT News Office, 2019; Shao, 2019).

Neo-racism suggests that discrimination is not criminal but actually warranted to preserve the U.S. imaginary of a safe, White-European country. This means immigration is still allowed and even encouraged, but only for a certain kind of immigrant - those who resemble the dominant race and culture. This attitude was most clearly evidenced when Trump referred to Haiti, El Salvador, and all of Africa as "shithole countries" while expressing we should have more migrants from places like Norway (Aizenman, 2018).

But what about our national security? Isn't racial profiling justified? Suspicions about immigrants and the hostile treatment of them as scapegoats, especially in times of economic downturn and crises, is unfortunately very common and very global. Among the recent political rhetoric is the anthropormorphizing of China as a person (Lewis, 2020). According to Margaret Lewis (2020), a negative stereotype is being 
built and reinforced that stigmatizes anyone who has any quality of being "likeChina" (Zhang, 2020, para 5). In Lewis' paper, she observed how the Department of Justice, including the FBI, depicts China as taking on a personified form, meaning that "China can steal" or "China can cheat" (Zhang, 2020, para 6). She goes on to argue that China itself, as an entire country, is not a perpetrator; rather, it is individuals. In effect, criminalizing China stigmatizes people who are seen as possessing a shared characteristic of "China-ness" (Lewis, 2020, p. 24). This typecast applies to Chinese Americans as well as Asian Americans. As mentioned earlier, this was manifested in random attacks for unwarranted blame for COVID-19. There also have been several high-profile cases of Chinese scientists being wrongfully accused of spying, and although these charges were dropped or the scientists were exonerated, such attempts led to "devastating effects" on the individuals' careers as well as the broader Chinese American scientific community (Committee of 100, 2019).

Neo-racism also occurs against Chinese students and within classrooms. Last year, we witnessed numerous U.S. universities making the news for faculty discriminating against Chinese students. A major research university in the East Coast made headlines when a professor was faulted for violating Chinese students' civil rights with sweeping claims, such as, "All Chinese students cheated their way into [the] United States" with threatened expulsion and deportation (Redden, 2019b). Faculty were similarly reported to have discriminated against Chinese students at numerous other U.S. universities (Redden 2019a, 2019b). In several of these cases, the accused professor resigned or was suspended from their respective position upon further investigation. Experts who have studied international students and faculty indicate such discriminatory incidents are not isolated events, but rather such "othering" is quite pervasive across U.S. higher education (Redden, 2019a; Suspitsyna \& Shalka 2019).

While national security should not be completely abandoned, the neo-racist criminalization of China actually undermines the United States. We must consider what are all the costs to internationalization. We are already expecting a major decline this year in university international enrollments and a consequent hit to the local economy. We should also consider academic freedom and humanitarian protection. There is even a cost to public health. In a recent paper, John Haupt and I (2020b) wrote about how the national securitization of COVID-19 has become a national over a humanitarian pursuit because the virus is politically framed as an existential danger coming from outside domestic borders, for which China is blamed. Examples are calling SARS-Co-V2 the "China Virus" or "Wuhan virus." We have also written about ways our ability to address the global pandemic are hindered when the government limits international engagement with China.

\section{CONCLUSION}

In conclusion, considering the risks to public health, personal freedoms, and rights, I and my collaborators argue that neo-racism undermines the United States' role as a global leader in higher education. With the rise of national protectionism, universities are and must remain international. Knowledge is fundamentally borderless, and yet higher education is being bordered by neo-racism. Neo-racist barriers to international 
migration, collaboration, and exchange limit higher education as well as our universities. Neo-racism limits our freedoms, limits our rights, and now limits our ability to respond to COVID-19 effectively. Neo-racist barriers must be called out and addressed.

\section{REFERENCES}

Aizenman, N. (2018, January 12). Trump wishes we had more immigrants from Norway. Turns out we once did. National Public Radio. https://www.npr.org/sections/goatsandsoda/2018/01/12/577673191/trumpwishes-we-had-more-immigrants-from-norway-turns-out-we-once-did

Allam, H. (2020, February 10). FBI announces that racist violence is now equal priority to foreign terrorism. National Public Radio. https://www.npr.org/2020/02/10/804616715/fbi-announces-that-racistviolence-is-now-equal-priority-to-foreign-terrorism

Balibar, E. (1992). Is there a 'neo-racism'? In E. Balibar \& I. Wallerstein (Eds.), Race, nation, class: Ambiguous identities (pp.17-28). Verso.

Cantwell, B., \& Lee, J. J. (2010). Unseen workers in the academic factory: Perceptions of neo-racism among international postdocs in the US and UK. Harvard Education Review, 80(4), 490-517.

Cantwell, B., Lee, J. J., \& Mlambo, Y. (2018). International graduate student labor as mergers and acquisitions. International Student Journal, 8(4), 1483-1498.

Castiello-Gutiérrez, S., \& Li, X. (2020). We are more than your paycheck. Journal of International Students, 10(3), i-iv. https://doi.org/10.32674/jis.v10i3.2676

Committee of 100. (2019). Committee of 100 condemns chinese american racial profiling [Press Release]. https://www.committee100.org/press_release/committee-of-100-condemnschineseamerican-racial-profiling-2/.

Lee, J. J. (2017). Neo-nationalism in higher education: Case of South Africa. Studies in Higher Education, 42(5), 869-886.

Lee J. J., \& Haupt, J. P. (2020a). Winners and losers in U.S.-China scientific research collaborations. Higher Education, 80, 57-74.

Lee, J. J., \& Haupt, J. P. (2020b). Scientific collaboration on COVID-19 amidst geopolitical tensions between the US and China. Research Square. https://doi.org/10.21203/rs.3.rs-37599/v1

Lee, J. J., Jon, J. E., \& Byun, K. (2017). Neo-Racism and neo-nationalism within Asia: The experiences of international students in South Korea. Journal of Studies in International Education, 21(2), 136-155.

Lee, J. J., \& Opio, T. (2011). Coming to America: Challenges and difficulties faced by African international student athletes. Sport, Education and Society, 16(5), $629-644$.

Lee, J., \& Rice, C. (2007). Welcome to America? International student perceptions of discrimination. Higher Education, 53(3), 381-409.

Lewis, M. (2020). Criminalizing China. Journal of Criminology Law and Criminology, 111(1). https://ssrn.com/abstract $=3600580$ 
MIT News Office. (2019). Letter to the MIT community: Immigration is a kind of oxygen. Retrieved from http://news.mit.edu/2019/letter-communityimmigration-is-oxygen-0625

President and Fellows of Harvard \& Massachusetts Institute of Technology vs U.S. Department of Homeland Security (2020). Civil Action No. 20-cv-11283-ADB. United States District Court District of Massachusetts. https://www.courtlistener.com/recap/gov.uscourts.mad.223165/gov.uscourts.ma d.223165.92.0_4.pdf

Redden, E. (2019a, February 5). Not an isolated incident. Inside Higher Ed. https://www.insidehighered.com/news/2019/02/05/weighing-duke-caseexperts-discuss-discrimination-against-international-students-and.

Redden, E. (2019b, March 21). Tensions over international students. Inside Higher Ed. https://www.insidehighered.com/news/2019/03/21/maryland-professorresigns-after-allegedly-making-discriminatorycomments-about.

Shao, E. (2019). President and provost release a statement reaffirming support for international community at Stanford. Stanford Daily. https://www.stanforddaily.com/2019/03/08/president-and-provost-releaseastatement-reaffirming-support-for-international-community-at-stanford/

Stein, S., \& de Andreotti, V. O. (2016). Cash, competition, or charity: International students and the global imaginary. Higher Education, 72(2), 225-239.

Suspitsyna, T., \& Shalka, T. R. (2019). The Chinese international student as a (post) colonial other: An analysis of cultural representations of a US media discourse. The Review of Higher Education, 42(5), 287-308.

Wang, C. (2020, April 14) Let's stop the scapegoating during a global pandemic. American Civil Liberties Union. https://www.aclu.org/news/racial-justice/letsstop-the-scapegoating-during-a-global-pandemic/

Zhang, J. (2020, August). Interview with Professor Margaret Lewis on China initiative. US-China Perception Monitor. https://uscnpm.org/2020/07/27/interview-with-professor-margaret-lewis-onchina-initiative/

JENNY J. LEE, PhD, is a professor at the Center for the Study of Higher Education at the University of Arizona. Professor Lee's research examines how policies, geopolitics, and social forces shape inequities in higher education, in the US and abroad. Her forthcoming edited book, "U.S. Power in International Higher Education," to be published by Rutgers University Press, will be released mid-2021. Email: jennylee@arizona.edu 